\title{
A SHORT REVIEW OF THE PROFESSIONALS AND GENERAL PUBLIC ATTITUDES AND CONCERNS ABOUT PHARMACOGENETIC TESTING WITH THE RECOGNITION OF THE PHARMACISTS ROLE
}

\author{
DUŠANKA M. KRAJNOVIĆ ${ }^{1 *}$, MARIJA M. LEVIĆ ${ }^{2}$, ADRIANA - ELENA TAEREL ${ }^{3}$ \\ ${ }^{I}$ Department for Social Pharmacy and Pharmaceutical Legislation, Faculty of Pharmacy, University of Belgrade, Belgrade, Serbia \\ ${ }^{2}$ PhD student at Department for Social Pharmacy and Pharmaceutical Legislation, Faculty of Pharmacy, University of \\ Belgrade, Belgrade, Serbia \\ ${ }^{3}$ Faculty of Pharmacy, "Carol Davila" University of Medicine and Pharmacy, Bucharest, Romania
}

*corresponding author: dusica.krajnovic@pharmacy.bg.ac.rs

Manuscript received: May 2018

\begin{abstract}
The present study had three main objectives: to investigate the attitudes and concerns of general public and patients about pharmacogenetic testing, to analyse the concerns and attitudes of professionals (healthcare workers and non-healthcare workers) about these tests and to examine the role of pharmacists. We conducted a review of original research studies using a structured approach of the following databases: PubMed, Scopus and Kobson, from 2004 to June 2015. A total of 22 studies fulfilled our criteria for inclusion, being related to the attitudes, concerns and beliefs of professional and general public regarding pharmacogenetic testing. In general, both professional and general public support pharmacogenetic testing. The main concern was the relative lack of knowledge in this field. Recognising the role of pharmacists, who will represent the connection between other providers of pharmacogenetic services and patients, is an important aspect. Implementation of the scientific evidences would lead to a significant improvement of pharmacogenetic testing processes.
\end{abstract}

\section{Rezumat}

Studiu a avut trei obiective principale: analizarea atitudinii şi preocupărilor pacienţilor privind testarea farmacogenetică, analizarea preocupărilor şi atitudinii profesioniştilor (personal din domeniul sanitar şi din domenii cu specific nesanitar) legat de această testare și evaluarea rolului farmaciştilor. Am sumarizat rezultatele unor studii originale de cercetare, folosind o abordare organizată a următoarelor baze de date cu caracter ştiinţific: PubMed, Scopus şi Kobson, din 2004 până în iunie 2015. Un număr de 22 de studii au îndeplinit criteriile de selecţie deoarece conţinutul lor corela atitudinile, preocupările şi viziunile profesioniştilor din domeniu şi a publicului larg, cu privire la testarea farmacogenetică. În general, atât profesioniştii, cât şi populația susţin testarea farmacogenetică. Principala preocupare face referire la lipsa relativă de informaţii din acest domeniu şi recunoaşterea rolului farmaciştilor de a reprezenta o punte de legătură între cei care oferă servicii în domeniul farmacogeneticii şi pacienţi. Implementarea noţiunilor ştiinţifice va conduce la dezvoltarea semnificativă a procesului de testare farmacogenetică.

Keywords: pharmacogenetic testing; attitudes; healthcare professionals; pharmacists

\section{Introduction}

Pharmacogenetics is a relatively young scientific discipline having its beginning in 1902, thanks to the English physician Garrod Archibald who noted that the way in which we react to therapy is due to "innate errors of metabolism" [1]. The first pharmacogenetic study was conducted in 1932 with a chemical compound phenylthiocarbamide, which confirmed that chemical compounds react differently, depending on the genetic characteristics of individuals. Friedrich Vogel has first used this term, presenting it as "clinically important genetic variation in response to drugs" and thus defined this comprehensive discipline [2]. After completion of the "Human Genome Project" in 2001 and the cognition of the human genome, the complexity of the biochemical pathways and the interaction of genes and their products, the term "pharmacogenomics" was introduced [3]. According to the World Health Organization, genetics studies the structure and function of individual genes, while genomics considers the entire genome, the relationship of genes and their influence on the body. For many, they remain synonymous to this day. But whichever the discipline, the objective is identical, and that is the individualization of therapy based on specific person genotype [4,5].

Polymorphism: the impact on pharmacokinetics and pharmacodynamics of drugs

The Food and Drug Administration (FDA) states that pharmacogenomics is an opportunity to identify new biomarkers that will accelerate the process of drug development. So far there are more than 198 agents with their pharmacogenetic findings included 
FARMACIA, 2018, Vol. 66, 5

in the FDA-approved labelling medicines. Drug labelling may contain information on genomic biomarkers and can describe: drug exposure and variability of clinical response; risk for adverse events; genotype-specific assessment; mechanisms of drug action; polymorphic drug target and disposition genes [6].

Polymorphism for enzymes involved in the metabolism of drugs, carriers, and/or drug's site of action can change the response to the drug and lead to unwanted reactions and treatment failure. So far, polymorphism is identified in more than 20 enzymes

involved in the metabolism of drugs. In some there are differences in frequency while in others specific phenotypic consequences are critical determinants of treatment outcomes. The most important genetic polymorphic enzymes are hepatic cytochrome P450 enzymes such as CYP1A2, CYP2C9, CYP2C19, CYP2D6, CYP3A4. They are responsible for the metabolism of most drugs, in its first phase. While in the second phase of metabolism, genetic polymorphic enzymes are UGT1A1 and TMPT. Detailed presentation of these enzymes with their substrates and functional consequences is shown in Table I $[7,8]$.

Table I

Polymorphism for enzymes involved in the metabolism of drugs [adapted from 8]

\begin{tabular}{|c|c|c|}
\hline Phase I metabolism & Functional consequences of polymorphism & Substrates for enzymes \\
\hline CYP1A2 & High inducibility & Caffeine, lidocaine, paracetamol \\
\hline CYP2C9 & Reduced activity & $\begin{array}{l}\text { Celecoxib, diclofenac, fluvastatin, ibuprofen, } \\
\text { clopidogrel, losartan }\end{array}$ \\
\hline CYP2C19 & Deficiency activity & Diazepam, omeprazole, propranolol \\
\hline CYP2D6 & $\begin{array}{l}\text { Deficiency activity and extremely high activity- } \\
\text { induced gene duplication }\end{array}$ & $\begin{array}{l}\text { Ajmaline, fluoxetine, haloperidol, } \\
\text { metoprolol, mexiletine, propafenone }\end{array}$ \\
\hline CYP3A4 & Slightly decreased activity & Erythromycin, nifedipine, paclitaxel \\
\hline \multicolumn{3}{|l|}{ Phase II metabolism } \\
\hline UGT1A1 & Reduced activity & Irinotecan \\
\hline TMPT & Deficiency activity & Azathioprine, 6-Mercaptopurine \\
\hline
\end{tabular}

DPYD: Dihydropyrimidinedehydrogenase, UGT1A1: uridinediphosphate-glucuronosyltransferase TPMT: Thiopurine S-methyl transferase

Besides enzymes involved in metabolism and pharmacological site of action may exhibit genetic polymorphism, and thus influence the response to the drug. The most common pharmacodynamic polymorphisms those are associated with the site of action leads to cardiac arrhythmia (mutation sodium and potassium channels), heart failure (mutation $\beta 2$ adrenoreceptor agonist), asthma (mutation $\beta 2$-adrenoreceptor agonist and a promoter 5-lipoxygenase), tuberculosis, depression (serotonin transporter mutation). So, polymorphism occurs both in genes encoding enzymes of metabolism, receptors and channels as well as in the genes responsible for the intracellular signal transduction [9, 10, 34].

Reply of individual may be different depending on whether they have or not genetic variations, and in this regard can be expected absence, excessive or inadequate response to a particular drug or group of drugs. Detection of genotype-phenotype correlation in the process of drug development, and demonstrate clinical validity and utility of the course of research will improve current drug therapy, ensure the achievement of better outcomes and certainly improve clinical practice. [13] Research conducted in the UK showed that the cause of admission to hospital due to adverse drug reactions had an incidence of $6.5 \%$. In the United States, $6.7 \%$ of all hospitalizations are due to serious adverse events, causing deaths in $0.37 \%$ of the cases. In this regard it is acknowledged the role of pharmacogenetic tests that will reduce adverse reactions to drugs, and improve the efficiency and safety of drugs [8].

The application of pharmacogenetics is not only for the treatment of diseases, but also for the development of new medicines and other products, such as vaccines. This technology has potential applications in the public vaccination programs for disease prevention, which would lead to the identification of the vaccine for small sub-populations genetically. The ethical reason for the application of pharmacogenetics in this case would be an extremely strong one, given that these vaccines do not only provide the wellbeing of the individual, but also for the benefit of the general population.

In recent years, more and more clinical trials include collecting and analysing DNA for approval of new drugs. This may involve testing samples taken from participants in the early stages of clinical testing in order to identify the pharmacogenetic effects in response to treatment, or testing patients during the phase of monitoring and supervision, if there are adverse reactions to drugs. These requirements are set by regulatory bodies, which deal with providing optimal conditions for the safe use of new drugs.

Pharmacogenetic testing offers many benefits for the patient: reducing of adverse effects by adjusting the appropriate drug or proper dose for each patient; probabilistic evaluation of efficacy; reference to the relevant therapeutic alternative that will be equally or more useful for the patient; reducing the time of 
treatment; detection of absolute or relative contraindications for prescribing medicines; reducing the cost of treatment by avoiding ineffective or harmful drugs; preventing unnecessary patient suffering. Data about the significant negative consequences of the application of pharmacogenetic testing in clinical practice is unknown until now $[11,12]$.

Given the great interest in this area that is in expansion we want to analyse the attitudes of both, professionals and general public, regarding pharmacogenetic testing and their opinion on how to deliver these services to patients in the healthcare system. We set three main objectives: to investigate the concerns' and attitudes of professionals (healthcare and nonhealthcare workers) about pharmacogenetic testing, to analyse the perspective and attitudes of the general public about pharmacogenetic testing and to examine the role of pharmacists in pharmacogenetic testing.

\section{Materials and Methods}

A structured search of the following databases was performed to retrieve published papers addressing professional and general public perspective on pharmacogenetic testing: PubMed, Kobson and Scopus. The electronic database search was carried out in the period from 2004 to 2015, and 906 articles were identified. Keywords that we used were: pharmacogenetic testing and opinions and general public or healthcare professionals or pharmacists. All articles with full text in English or Serbian language were taken into account, if they meet all necessary criteria. Two investigators (ML and DK) independently performed the literature search and the collection of publications and gave the assessment of the requirements for inclusion in the analysis of publications. Inclusion criteria were: original papers that were oriented to attitudes and concerns of general public or patients or professionals toward pharmacogenetic testing, papers oriented to pharmacists and their role in the pharmacogenetic testing services. After a brief review of abstracts and results, some articles were eliminated because they were not related to pharmacogenetic testing, case reports/reviews/editorials/ abstracts/qualitative studies and available only as abstracts. Standardized data collection tool was used to characterize each study taken into consideration.

\section{Results and Discussion}

In the first search we identified 906 citations and conducted extraction following the strategy presented in Figure 1. First, we removed 173 duplicates and 475 studies that were not related to the pharmacogenetic testing, 150 reviews and editorials, 29 review articles and 48 abstracts. A total of 875 citations were excluded. After the full-text review we excluded 9 studies that did not relate to the attitudes and concerns of pharmacogenetic testing, did not have the full article available or did not refer to the role of pharmacists in pharmacogenetic testing. After the final selection, 22 studies fulfilled the inclusion criteria [11, 14-36]. Distribution of articles by publication year was presented at Figure 2. Articles were dominantly from the 2011 and 2012 years $(36.36 \%)$.

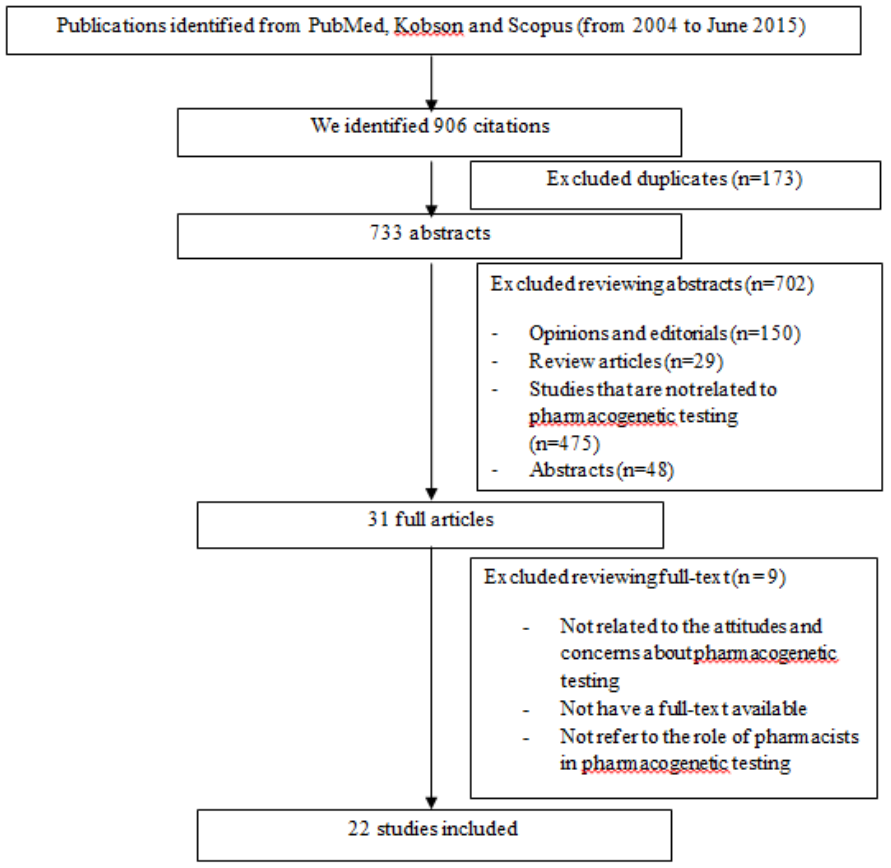

Figure 1.

Structured search strategy 
FARMACIA, 2018, Vol. 66, 5

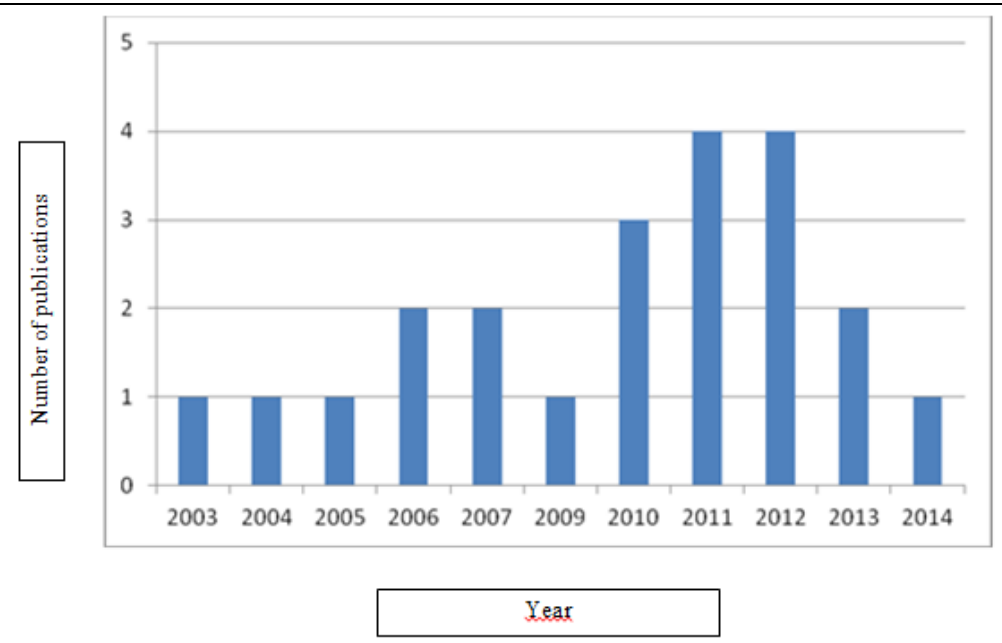

Figure 2.

Number of publications identified by years (analysed by the year of publication)

Geographical distribution of the journals shows that studies were mostly published in international journals $19(86.36 \%)$ and 13 American journals (64\%). Among the 22 analysed studies [11, 13-33], only 2 $(9.09 \%)$ referred to attitudes and concerns of the general public, patients $7(31.82 \%)$ and professionals 5 $(22.73 \%)$, while a quarter of them $40.91 \%$ ( 9 papers) examined and presented the role of pharmacists in pharmacogenetic testing.

We identified several attitudes and concerns of professionals and general public about pharmacogenetics testing. We used the term general public only to refer to non-patients. These attitudes are both positive and negative, and they vary depending on age and the existence of previous experiences with adverse events to medicines, as well as the origin of the respondents. Concerns are related to the privacy of their results and the lack of knowledge about the pharmacogenetic testing services (Table II). There were the differences of opinion of the general public about the additional information and their impact on psychological health. Professionals, divided as healthcare professionals and other experts involved in the provision of pharmacogenetic testing services generally support the testing and have a willingness to participate. Pharmacists as the object of our interest, were considered separately. Our next objective was to determine if the role of pharmacists in providing these services is recognized and whether it is negative or positive.

Table II

Summarized results about attitudes and concerns of professionals and general public regarding pharmacogenetic

\begin{tabular}{|c|c|c|c|c|c|}
\hline & General public & Patients & $\begin{array}{c}\text { Healthcare } \\
\text { workers } \\
\end{array}$ & $\begin{array}{c}\text { Non-healthcare } \\
\text { workers }\end{array}$ & Pharmacists \\
\hline \multicolumn{6}{|l|}{ Attitudes } \\
\hline $\begin{array}{c}\text { Approve } \\
\text { pharmacogenetic } \\
\text { testing }\end{array}$ & $\begin{array}{c}\text { Depending on the age } \\
\text { and previous negative } \\
\text { experience with adverse } \\
\text { reactions to drugs } \\
\end{array}$ & $\begin{array}{l}\text { Expressed } \\
\text { willingness to } \\
\text { undergo testing }\end{array}$ & $\begin{array}{l}\text { Think that patient } \\
\text { have benefit from } \\
\text { pharmacogenetic } \\
\text { testing }\end{array}$ & $\begin{array}{c}\text { Have a positive } \\
\text { opinion }\end{array}$ & $\begin{array}{c}\text { Great interest in } \\
\text { community pharmacy } \\
\text { for testing and } \\
\text { counselling patients }\end{array}$ \\
\hline $\begin{array}{l}\text { Healthcare } \\
\text { professionals } \\
\text { explain the test } \\
\text { and result }\end{array}$ & $\begin{array}{l}\text { Consider this as } \\
\text { necessary }\end{array}$ & \begin{tabular}{|c|} 
Expect a good \\
explanation of the \\
pre-trained \\
healthcare \\
professionals \\
\end{tabular} & $\begin{array}{l}\text { Believe that they } \\
\text { should participate }\end{array}$ & $\begin{array}{l}\text { Think that they } \\
\text { should be } \\
\text { involved in the } \\
\text { interpretation of } \\
\text { test results }\end{array}$ & $\begin{array}{l}\text { Believe that pharmaco- } \\
\text { genomics will have a } \\
\text { major impact on their } \\
\text { role in improving the } \\
\text { patient's health }\end{array}$ \\
\hline $\begin{array}{c}\text { Role of } \\
\text { pharmacists in } \\
\text { pharmacogenetic } \\
\text { testing }\end{array}$ & $\begin{array}{c}\text { Recognize the role } \\
\text { of pharmacists }\end{array}$ & $\begin{array}{c}\text { No preference } \\
\text { which healthcare } \\
\text { professionals will } \\
\text { be involved }\end{array}$ & $\begin{array}{c}\text { Find that they have } \\
\text { a major role }\end{array}$ & $\begin{array}{l}\text { Want to cooperate } \\
\text { with pharmacists }\end{array}$ & $\begin{array}{l}\text { See themselves in this } \\
\text { role especially in } \\
\text { counselling patients }\end{array}$ \\
\hline \multicolumn{6}{|l|}{ Concerns } \\
\hline $\begin{array}{c}\text { Lack of } \\
\text { knowledge about } \\
\text { pharmacogenetic } \\
\text { testing }\end{array}$ & $\begin{array}{c}\text { Concerned about the } \\
\text { lack of knowledge } \\
\text { in this field }\end{array}$ & $\begin{array}{c}\text { Expect timely and } \\
\text { accurate } \\
\text { information but } \\
\text { they are not sure } \\
\text { about that }\end{array}$ & \begin{tabular}{|c|} 
Find that they need \\
additional education \\
and $80 \%$ physicians \\
stated that they had \\
never recommended \\
testing
\end{tabular} & $\begin{array}{c}\text { Considered they } \\
\text { have sufficient } \\
\text { knowledge about } \\
\text { pharmacokinetics } \\
\text { and pharmaco- } \\
\text { dynamics of drugs }\end{array}$ & $\begin{array}{l}\text { Most pharmacists } \\
\text { believe that their } \\
\text { advice is poor or even } \\
\text { very poor and } \\
\text { highlight the need for } \\
\text { further education } \\
\end{array}$ \\
\hline
\end{tabular}


FARMACIA, 2018, Vol. 66, 5

\begin{tabular}{|c|c|c|c|c|c|}
\hline $\begin{array}{c}\text { Additional } \\
\text { information for } \\
\text { respondents }\end{array}$ & $\begin{array}{c}\text { While some think } \\
\text { that receiving } \\
\text { unwanted test } \\
\text { results adversely } \\
\text { affect their } \\
\text { psychological } \\
\text { health, others see } \\
\text { benefit from them }\end{array}$ & $\begin{array}{c}\text { They are } \\
\text { concerned about } \\
\text { acceptance of } \\
\text { these information }\end{array}$ & $\begin{array}{c}\text { The majority of } \\
\text { physicians agreed to } \\
\text { reveal helpful } \\
\text { information about } \\
\text { testing to patients }\end{array}$ & $\begin{array}{c}\text { Geneticists } \\
\text { believed that it } \\
\text { depends on the } \\
\text { "case by case" }\end{array}$ & $\begin{array}{c}\text { Believe that through } \\
\text { genetic counselling } \\
\text { can be psychological } \\
\text { support to patients }\end{array}$ \\
& & & & \\
\end{tabular}

Results about summarizing the attitudes and concerns of patients and the general public Attitudes

As for the attitudes of the general public on pharmacogenetic testing, most of them justified and expressed willingness to undergo testing. Specifically, younger people showed more interest in pharmacogenetic testing. This is the case with respondents who have had previous negative experiences with adverse reactions to drugs.

Patients as most users of these services, generally, have a positive attitude about pharmacogenetic testing. It was found that patients who have had previous experiences with adverse reactions to drugs and those who are afraid of the potential in future show interest and provide greater support for this service $[15,36]$.

Patients expect that healthcare workers who provide pharmacogenetic services should explain the test and interpret the implications of the regulation [16]. In the UK conducted studies showing that patients do not have a preference in terms that health workers should provide pharmacogenetic services but they give priority to timely and accurate information about the usefulness of testing and its impact on their health [17] as well as a good explanation of the pre- trained health workers [16]. When asked which health workers would they hold responsible for distributing and storing the results of pharmacogenetic testing for their re-use if needed, patients have declared that they would feel very safe to share their results with other doctors in their healthcare. Regarding pharmacists, patients also agreed that they should be included in distributing and storing the results of pharmacogenetic testing for their re-use, but patients have less confidence in pharmacists than in doctors [14].

Concerns

Opinions were divided among general public when considered the issue of additional information that the respondents received. While some felt that the communication of adverse test results in detrimental effects on their psychological health, others pointed out that it will not endanger their health or any decision of pharmacogenetic testing. Again, public attitudes toward pharmacogenetic testing depends on the country of origin. For example, in Poland, the participants unanimously supported the testing, while respondents from the United Kingdom and the United States showed a dose of reservation [18]. As one of the problems patients highlighted a general lack of knowledge of pharmacogenetic testing [19]. Also, as major obstacles, the patients stand out the privacy issues regarding their genetic information and test results and the costs of testing and insurance coverage $[15,20]$.

Results about the attitudes and concerns of professionals (healthcare and non-healthcare workers)

Attitudes

Healthcare workers believe that patients have benefit from pharmacogenetic testing. They see themselves in the major role with the mandatory participation [21]. Genetic counsellors considered that they should be involved in the interpretation of test results and want to cooperate with pharmacists [22].

The survey of physicians and geneticists about extra information has led to the following results: the majority of physicians agreed to reveal helpful information about testing patients while geneticists believe that it depends on the "case by case" [23].

\section{Concerns}

Some studies have stated that the lack of knowledge and clinical evidence are the greatest barriers to the implementation of this approach [11]. $80 \%$ of physicians stated that they had never recommended testing, although they are considered as primary providers of these services [21]. Problems cited were the influence of time needed for pharmacogenetic testing that delays treatment and storage of test results in medical records [23].

It was found that service providers used to limit patient access to information in connection with pharmacogenetic testing, example of this is the test for trastuzumab, and the reason is to avoid disappointment if the patient is not "appropriate" for therapy [24].

Attitudes and concerns of pharmacists

It was determined that most pharmacists have a positive opinion about the perceived benefits of pharmacogenetic testing, and agree that part of their role should be patient counselling regarding information on pharmacogenetic testing, in particular for "one to one" contact between patients and pharmacists. There is a great interest of pharmacists in community pharmacy for testing and willingness to consult patients about the results.

When pharmacists were questioned about their views on the ethical implications of genetic testing, most of 
them showed concern about insurance companies which can use the results of pharmacogenetic testing to deny health coverage. Genetic Information Nondiscrimination Act (GINA) adopted on 21 May 2008 in the United States prohibits discrimination by health insurers and employers based on genetic information, including the results of genetic testing of patients and their families. However, the impression is that healthcare providers are not familiar with it, and therefore there is concern about the denial of health coverage. Future training for pharmacists should focus on ethical issues in order to ensure feasibility in clinical practice [25].

Results about the role of pharmacists in pharmacogenetic testing

Pharmacogenetics provides a unique opportunity for pharmacists who will be the connection between other providers of pharmacogenetic services and patients. Pharmacists can use their knowledge of pharmacokinetics and pharmacodynamics, and thus help doctors to choose the right drug, the correct dose and enable avoidance of adverse effects. They are also involved in patient education, recommending testing to patients and reporting on the results of tests. However, their knowledge of genetics is not enough, which should include genetic counsellors, who will deal with specific issues regarding testing [22]. There are numerous models of providing pharmacogenetic services by pharmacists. St. Jude Children's Hospital in Nashville, TN (USA) has implemented a clinical pharmacogenetic service, where the clinical pharmacists have an active role in reviewing the test results and in recommending the selection of therapy [26]. Also, their role in providing pharmacogenetic testing in the framework of public pharmacies is well-researched and analysed. Pharmacists in public pharmacies are an integral part of patientcare through the Medication Therapy Management (MTM). Pharmacists have developed a relationship with patients and they are ready to provide clinical services in response to the results of pharmacogenetic testing. This will only lead to an extension of their current roles towards an insight into the results and recommendation of their opinion. In community pharmacies this project would not have succeeded without the establishment of relations with associates. Each collaborator fills an important role and brings significant resources, expertise and experience, which should be taken into account when establishing pharmacogenetic services [27].

Genetic counselling aims to facilitate people making decisions about testing, to ensure a common understanding of genetic variation, and to provide psychological support after the test [28]. Bearing in mind that in many countries it requires counselling patients by pharmacists, this role is expected in the process of genetic counselling also.

\section{Attitudes}

Pharmacists think that pharmacogenomics will have a major impact on their role in improving the patient's health [29]. In North Carolina (USA) were observed favourable attitudes of pharmacists regarding pharmacogenetic testing and the existence of a desire to learn more about this impressive discipline [30].

In Australia it is conducted a research among pharmacists, where counselling is seen as one of the areas of pharmacy practice that pharmacogenetics will have the greatest impact on. The attitudes of pharmacists in terms of counselling have led to the following statements: pharmacogenetics could lead to an increased demand for consulting and therefore requiring a longer time spent with the patient; regarding the complexity of counselling, pharmacogenetics improve the ability of the pharmacist in counselling patients; pharmacogenetic information will assist in optimizing therapies; the impact of pharmacogenetics to the pharmaceutical profession would depend on the availability of test results and the patient's willingness to disclose details about their genetic profile.

\section{Concerns}

In order to ensure appropriate high standards of counselling and pharmaceutical care there is a need for future education and understanding of pharmacogenetics by pharmacists. The proposal is that the training is carried out within the framework of the faculty studies, as well as seminars and workshops which are an integral part of their continuing professional development [29].

It is proposed a partnership of genetic counsellors and pharmacists that will enable the provision of comprehensive services to physicians and patients about the proper use of tests based on known evidence [22]. There were identified certain barriers in this approach. [31] Those are relating to: preparing genetic counsellors and pharmacists to provide pharmacogenetics testing services [32], limitation of the workforce genetic counsellor [33], benefits of patients and professionals [14], tests readiness [34] and reimbursement [35].

With the advent of pharmacogenetics begins the era of personalized medicine, which will identify the best drug for a given patient, and also the most effective and safest dose from the start of drug administration. This approach to the treatment of diseases is promising compared to the traditional "one size fits all" approach. With the discovery of the entire human genome public and healthcare professionals expect that all doubts and failures to be avoided. Expectations are high and it is hoped that each patient will possess a card with a microchip that will contain its genetic information in order to provide highly individualized therapy, being acknowledged the great advances in 3D printing techniques applied in drugs manufacturing 
FARMACIA, 2018, Vol. 66, 5

$[12,13]$. Legislation on this matter has certain characteristics: apply to tests in order to achieve certain health conditions, protect the autonomy, integrity and privacy of people tested, sets the requirements for the process of genetic counselling and mechanisms in order to preserve the quality of the tests. Laws in Germany, Sweden and Switzerland allow testing under certain conditions in terms of insurance. These countries allow the use of genetic information for risk assessment if the amount of insurance exceeds a specified level, while Austria, France and Portugal explicitly forbid using genetic information in the context of insurance. In the absence of specific laws relating to the field of genetics, general legal framework covering the area of health refers to the doctor-patient relationship, professional ethics, compliance, health performance, privacy and confidentiality, and may apply also to genetic tests. The role of regulations is to facilitate the practice and interests of the community by setting appropriate conditions and framework for conducting genetic activity and it serves to ensure public confidence [20].

Our findings suggest that generally, professionals and general public support pharmacogenetic testing. Increasing the efficacy of the drug, avoiding side effects and personalized care are the most frequently cited reasons for approval. However, it is highlighted the relative lack of knowledge in the field of pharmacogenetics, which was the main cause for concern. General public has shown concerns about privacy and the possibility of misuse of genetic information by insurance companies. Similar concerns are shared by healthcare and non-healthcare workers. Although general public has shown a desire to receive the test results, healthcare providers do not fully agree with that, the reason is the potential psychological harm to the patient. It is necessary to do research on under-represented minority groups in order to identify specific obstacles.

As for the role of pharmacists, certainly, it is necessary to engage in pharmacogenetic testing, because their knowledge and skills contribute to the process with the ultimate goal of improving public health. There are several models and different strategies for delivering pharmacogenetic testing, but whether healthcare workers will be involved, and there will be a collaborative model, it depends on the type of test to be used, the connection with the complexity of information and the implications for the patient's health.

\section{Limitations}

We would like to point out several limitations of this research: it was searched a relatively small number of databases to find full papers. Keywords that were used may not be comprehensive for finding relevant work. Then, the power of this study was limited by the short time frame for search and the access to some full papers

\section{Conclusions}

We performed a literature review with a structured approach to assess the attitudes and concerns of professionals (healthcare and non-healthcare workers), general public and patients regarding pharmacogenetic testing. The common theme of all stakeholders was the support of pharmacogenetic testing and the relative lack of knowledge, while concern about privacy, cost and the spread of the test results differed among the groups. The role of pharmacists is recognized, particularly in the process of genetic counselling. Pharmacogenetic testing techniques will develop, requiring more guidance in this area. Awareness of these issues will help to facilitate the implementation of pharmacogenetic tests by pharmacists and other professionals, if the promise of personalized medicine is completed and it is implemented with all its potential.

\section{Acknowledgement}

This paper was performed under the Agreement of Cooperation between the Faculty of Pharmacy, University of Belgrade (Serbia) and The Faculty of Pharmacy, "Carol Davila" University of Medicine and Pharmacy Bucharest (Romania). The work of Dušanka Krajnović was partially supported by the grant of Ministry of Education, Science and Technological Development in Serbia, Grant Number 41004.

\section{Conflict of interests}

The authors declare no conflict of interests.

\section{References}

1. Archibald G, The incidence of alkaptonuria: a study in chemical individuality. Lancet, 1902; 1616-1620.

2. Vogel F, Moderne Probleme der Humangenetik. Ergeb Inn Med Kinderheilkd., 1959; 52-125. (available in German)

3. Phillips KA, Veenstra DL, Oren E, Lee JK, Sadée $\mathrm{W}$, Potential role of pharmacogenomics in reducing adverse drug reactions. JAMA, 2001; 2270-9.

4. Otelea MR, Rascu A, Genomics and proteomics technique in nanoparticles studies new approach in environmental research. Environmental Engineering and Management Journal, 2015; 14(10): 2283- 2291.

5. Rang HP, Dale MM, Ritter JM, Flower RJ, Henderson G, Pharmacogenetics, pharmacogenomics and personalized medicine. In Rang HP, Dale MM, Ritter JM, Flower RJ, Henderson G, Edinburgh, London, New York, Oxford, Philadelphia, St Louis, Sydney, Toronto: Elsevier Churchill Livingstone, 2012. 
FARMACIA, 2018, Vol. 66, 5

6. US Food and Drug Administration. Table of Pharmacogenomic Biomarkers in Drug Labeling, /www.fda.gov.

7. Abdelhedi R, Kharrat N, Maurer M, Abdelmoula NB, Abid L, Laroussi L, Kammoun S, Rebai T, Rebai A, Impact of clopidogrel plasmatic levels, CYP2C19 polymorphisms and drug-drug interactions on clinical outcome in coronary artery disease patients. Farmacia, 2018; 66(1): 135-148.

8. Prostran M, Stojanović R, Savić KV, Medić B, Divac N, Osnovi farmakogenetike i farmakogenomike. Monografije naučnih skupova AMN SLD, 2014. (available in Serbian)

9. Shah RR, Pharmacogenetics in drug regulation: promise, potential and pitfalls. Philos Trans $R$ Soc Lond B Biol Sci., 2005; 360(1460): 1617-1638.

10. Rais C, Taerel AE, Stefanescu E, Brumărel M, Safta V, Adauji S, Priscu V, Soroceanu V, Epidemiological aspects of tuberculosis in adults in Romania versus the Republic of Moldova. Farmacia, 2016; 64(1): 152-158.

11. Netzer C, Biller-Andorno N, Pharmacogenetic testing, informed consent and the problem of secondary information. Bioethics, 2004; 18(4): 344-3460.

12. Dumitrescu IB, Lupuliasa D, Drăgoi CM, Nicolae AC, Pop A, Şaramet G, Drăgănescu D, The age of pharmaceutical 3D printing. Technological and therapeutical implications of additive manufacturing. Farmacia, 2018; 66(3): 365-389.

13. Motofei IG, Rowland DL, Păunică I, Tănăsescu OC, Banu P, Păunică S, Finasteride as a model for personalized medicine. J Mind Med Sci., 2017; 4(2): $125-131$

14. Haga SB, Kawamoto K, Agans R, Ginsburg GS, Consideration of patient preferences and challenged in storage and access of pharmacogenetic test results. Genet Med., 2011; 3(10): 887-890.

15. Rogausch A, Prause D, Schallenberg A, Brockm€oller J, Himmel W, Patients and physicians' perspectives on pharmacogenetic testing. Pharmacogenomics, 2007; 7(1): 49-59

16. Fargher EA, Eddy C, Newman W, Qasim J, Tricker K, Elliott RA, Payne K, Patients' and healthcare professionals' views on pharmacogenetic testing and its future delivery in the NHS. Pharmacogenomics, 2007; 8(11):1511-1519.

17. Payne K, Fargher EA, Roberts SA, Tricker K, Elliott RA, Ratcliffe J, Newman WG, Valuing pharmacogenetic testing services: a comparison of patients' and health care professionals' preferences. Value Health., 2011; 14(1): 121-134.

18. Patel HN, Ursan ID, Zueger PM, Cavallari LH, Pickard AS, Stakeholder views on pharmacogenetic testing. Pharmacotherapy, 2015; 34(2):151-65.

19. O'Daniel J, Lucas J, Deverka P, Factors influencing uptake of pharmacogenetic testing in a diverse patient population. Public Health Genomics, 2010; 13(1): 48-54.

20. Soini S, Genetic testing legislation in Western Europe - A fluctuating regulatory target. $J$ Community Genet., 2012; 3(2): 143-153.
21. Haga S, Burke W, Ginsburg GS, Mills R, Agans R, Primary care physicians' knowledge of and experience with pharmacogenetic testing. Clin Genet., 2012; 82(4); 388-894.

22. Mills R, Haga $S$, The clinical delivery of pharmacogenetic testing services: a proposed partnership between genetic counselors and pharmacists. Pharmacogenomics, 2013; 14(8): 957-968.

23. Haga S, O’Daniel JM, Tindall GM, Mills R, Lipkus IM, Agans R, Survey of genetic counselors and clinical geneticists' use and attitudes towarysd pharmacogenetic testing. Clin Genet., 2010; 82(2): 115-120.

24. Hedgecoe A, At the point at which you can do something about it, then it becomes more relevant": informed consent in the pharmacogenetic clinic. Soc Sci Med., 2005; 61(6): 1201-1210.

25. Haynes K, Zayac C, Sprague JE, Bernhardt B, Pyeritz $\mathrm{R}$, Community pharmacists' attitudes towards clinical utility and ethical implications of pharmacogenetic testing. Per Med., 2013; 10(8): 793-800.

26. Crews KR, Cross SJ, McCormick JN, Baker DK, Molinelli AR, Mullins R, Relling MV, Hoffman $\mathrm{JM}$, Development and implementation of a pharmacistmanaged clinical pharmacogenetics service. $A m J$ Health Syst Pharm., 2011; 68(2): 143-50.

27. O'Connor SK, Ferreri SP, Michaels NM, Chater RW, Viera AJ, Faruki H, Making pharmacogenetic testing a reality in a community pharmacy. $J \mathrm{Am}$ Pharm Assoc (2003)., 2012; 52(6): e259-e265.

28. Ellingro VL, Moline J, Incorporating Pharmacogenomics into Practice. J Pharm Pract., 2007; 20: 277-282.

29. McMahon T., Tucci J., The perceptions of pharmacists in Victoria, Australia on pharmacogenetics and its implications. Pharmacy Practice, 2011; 9(3): 141-147.

30. Roederer M, Van Riper M, Valgus J, Knafl G, McLeod H, Knowledge, attitudes and education of pharmacists regarding pharmacogenetic testing. Pers Med., 2012; 9(1): 19-27.

31. Tăerel AE, Soroceanu V, Rais C, Stancu E, Study of quality standards application in Bucharest community pharmacies. Farmacia, 2014; 62(6): 1082-1088.

32. Sansgiry SS, Kulkarni AS, The human genome project: assessing confidence in knowledge and training requirements for community pharmacists. $\mathrm{Am} \mathrm{J}$ Pharmaceutical Education, 2003; 67(2): 1-10.

33. Lea DH, Williams JK, Cooksey JA, Flanagan PA, Forte G, U.S. genetic nurses in advanced practice. $J$ Nurs Scholarsh., 2006; 38(3): 213-218.

34. Hoop JG, Lapid MI, Paulson RM, Roberts LW, Clinical and ethical considerations in pharmacogenetic testing: views of physicians in 3"early adopting" departments of psychiatry. J Clin Psychiatry., 2010; 71(6): 745-753.

35. Mester JL, Trepanier AM, Harper CE, Rozek LS, Yashar BM, Uhlmann WR, Perceptions of licensure: a survey of Michigan genetic counselors. J Genetic Counseling, 2009; 18(4): 357-365.

36. Zugravu CA, Baciu A, Patrascu D, Tarcea M, Stoian A, Depression and diabetes: are there any consequences on self-care?. Eur J Public Health, 2012; 22(2): 272-272. 